\title{
PRODUCTION OF LETTUCE UNDER GREEN MANURING WITH Calotropis procera IN TWO CULTIVATION SEASONS ${ }^{1}$
}

\author{
ÊNIO GOMES FLÔR SOUZA ${ }^{2 *}$, EDSON FERREIRA DE LIMA ${ }^{3}$, AURÉLIO PAES BARROS JÚNIOR ${ }^{4}$, LINDOMAR \\ MARIA DA SILVEIRA ${ }^{4}$, FRANCISCO BEZERRA NETO $^{4}$, ELLEN ABREU DA CRUZ ${ }^{2}$
}

\begin{abstract}
The production of vegetable crops is characterized by intensive land use, high input demands and the requirement of strategic management adoption with an agro-ecological approach. In this study, agronomic indicators were evaluated in lettuce fertilized with different amounts of roostertree biomass; fertilizer was incorporated into the soil at distinct times and seedlings were planted in two cropping seasons (spring and autumn-winter) in Serra Talhada, Pernambuco state, Brazil. The experimental design consisted of randomized complete blocks with three replications and treatments arranged in a $4 \times 4$ factorial scheme. The first factor was the amounts of roostertree biomass $\left(5.4,8.8,12.2\right.$, and $15.6 \mathrm{t} \mathrm{ha}^{-1}$ on a dry basis) and the second the manure incorporation times $(0,10,20$, and 30 days before lettuce transplanting). The variables evaluated in the lettuce crop were: plant height and diameter, number of leaves per plant, productivity of green mass, and dry shoot mass. Maximum productivity and dry shoot mass were obtained using fertilization with $15.6 \mathrm{tha}^{-1}$. A synchrony between supply of nutrients by green manure and the period of maximum demand by lettuce was observed in the incorporation times of 10 (spring) and 20 (autumn-winter) days before transplanting. Cultivation in the spring resulted in higher vegetative growth.
\end{abstract}

Keywords: Lactuca sativa L.. Roostertree. Organic cropping.

\section{PRODUÇÃO DE ALFACE SOB ADUBAÇÃO VERDE COM Calotropis procera EM DUAS ÉPOCAS DE CULTIVO}

\begin{abstract}
RESUMO - A produção de hortaliças é caracterizada pelo uso intensivo da terra, pela alta demanda de insumos e pela necessidade de gestão estratégica com uma abordagem agroecológica para sustentar a produção. Indicadores agronômicos foram avaliados em alface adubada com diferentes quantidades de biomassa de Florde-seda, em diferentes épocas de incorporação ao solo e plantadas em duas estações de cultivo (primavera e outono-inverno) em Serra Talhada, Pernambuco, Brazil. O delineamento experimental consistiu em blocos ao acaso com três repetições e os tratamentos arranjados em esquema fatorial $4 \times 4$. O primeiro fator foi à quantidade de biomassa de Flor-de-seda $\left(5,4 ; 8,8 ; 12,2\right.$ e $15,6 \mathrm{t} \mathrm{ha}^{-1}$ em base seca) eo segundo os tempos de incorporação do adubo $(0,10,20$ e 30 dias antes do transplante da alface). As características avaliadas na cultura da alface foram: diâmetro de plantas, número de folhas por planta, altura de plantas, produtividade de massa verde e massa seca da parte aérea. As produtividades máximas de massa verde e seca foram obtidas na quantidade de biomassa de Flor-de-seda de 15,6 t ha ${ }^{-1}$ incorporada no solo. Observou-se uma sincronia entre a oferta de nutrientes pelo adubo verde e o período de máxima demanda pela alface nos tempos de incorporação de 10 (primavera) e 20 dias (outono-inverno) antes do transplantio. O cultivo na primavera resultou em maior crescimento vegetativo para a cultura.
\end{abstract}

Palavras-chave: Lactuca sativa L.. Flor-de-seda. Cultivo orgânico.

${ }^{1}$ Received for publication in $08 / 04 / 2015$; accepted in $08 / 15 / 2016$

Paper extracted from the master thesis of the second author.

${ }^{2}$ Instituto Federal de Alagoas, Piranhas, AL, Brazil; enio.souza@ifal.edu.br, ellenabreu@hotmail.com.

${ }^{3}$ Instituto Federal de Alagoas, Santana do Ipanema, AL, Brazil; edsonmestrando@hotmail.com.

${ }^{4}$ Department of Crop Science, Universidade Federal Rural do Semi-Árido, Mossoró, RN, Brazil; aurelio.barros@ufersa.edu.br, lindomarmaria@ufersa.edu.br, bezerra@ufersa.edu.br.
} 


\section{INTRODUCTION}

Lettuce (Lactuca sativa L.) is a major vegetable crop in Brazil, with broad social and economic importance. In northeastern Brazil, lettuce presents cultivars adapted to local climatic conditions, early cycle, low incidence of pests and diseases, in addition to good market acceptance. To obtain quality lettuce around the year, adequate planting planning, mainly observing the microclimates in each region, the growing season of each variety, and production costs, is required.

The majority of lettuce cultivation is carried out on family farms using basic labor and cattle, goat, or sheep manure as fertilizer. If organic fertilizers are sourced from outside the properties, production costs increase or technical restrictions might apply (SILVA et al., 2011).

The use of natural fertilizers from the property itself is of fundamental importance for these agricultural production systems, especially in terms of green manuring. This technique includes incorporation of plant debris, produced on site or sourced from other farms, in order to preserve and/or restore soil organic matter and nutrients (OLIVEIRA et al., 2011).

Research conducted in the semiarid region of the state Rio Grande do Norte has proven the shown agronomic and economic viability of the use of spontaneous plants such as roostertree (Calotropis procera (Ait.) R. Br.), hairy woodrose (Merremia aegyptia L.), and oneleaf senna (Senna uniflora L.) as green manure in the production of broadleaf and root vegetable crops (LINHARES, 2009; BEZERRA NETO et al., 2011; SILVA et al., 2011; BATISTA et al., 2013; BEZERRA NETO et al., 2014; ALMEIDA et al., 2015). Among these species, C. procera has shown the greatest drought resistance; it is able to produce biomass even under severe drought conditions (ANDRADE et al., 2008; CARVALHO JÚNIOR et al., 2010).

In addition to the effects of soil conditions, $L$. sativa significantly responds to climatic factors. According to Kenter, Hoffmann and Marlander (2006), who evaluated the impacts of climatic conditions on growth and development of vegetable crops, experiments must be conducted at different growing seasons, different from approaches used by previous studies. To date, there are no studies evaluating the influence of weather conditions on the production potential of lettuce and the mineralization time of green manure in the Brazilian semiarid region.

The objective of this research was therefore to evaluate $L$. sativa production under different amounts of roostertree biomass and different incorporation times to the ground in two growing seasons (spring and autumn-winter) under field-conditions of Serra Talhada, Pernambuco.

\section{MATERIAL AND METHODS}

All experiments were conducted in the field in two growing seasons: spring (September 16 to November 18, 2011) and autumn-winter (May 20 to July 24, 2012) at the Universidade Federal Rural de Pernambuco (UFRPE), Academic Unit of Serra Talhada (UAST), in the micro region of the Pajeú, north of Pernambuco ( $7^{\circ} 57^{\prime} 15^{\prime \prime}$ south latitude and $38^{\circ} 17^{\prime} 41^{\prime \prime}$ west longitude), at $461 \mathrm{~m}$ asl. According to the Köppen classification, climate is Bwh, is semiarid, warm, and dry with summer rains; average annual temperature is $24.7^{\circ} \mathrm{C}$ and average annual rainfall $642.10 \mathrm{~mm}$ (SUDENE, 1990; MEDEIROS et al., 2005). Figure 1 shows the average meteorological data during the experimental period.



Sep/11 Oct/11 Nov/11 May/12 June/12 July/12

Figure 1. Mean monthly values $\left({ }^{\circ} \mathrm{C}\right)$ of instantaneous, maximum, and minimum temperatures, solar radiation $\left(\mathrm{MJ} \mathrm{m}^{-2}\right.$ day $\left.^{-1}\right)$, and photoperiod $(\mathrm{h})$ in each cropping season of $L$. sativa. 
The soil of the experimental area had a sandy loam texture, with the following chemical characteristics at a depth of $0-20 \mathrm{~cm}$ in spring (prior to the start of the experiments): $\mathrm{pH}$ in $\mathrm{H}_{2} \mathrm{O}$ $(1: 2.5)=7.2 ; \mathrm{OM}=12.8 \mathrm{~g} \mathrm{~kg}^{-1} ; \mathrm{P}=14.0 \mathrm{mg} \mathrm{dm}^{-3}$; $\mathrm{K}^{+}=0.5 \mathrm{cmol}_{\mathrm{c}} \mathrm{dm}^{-3} ; \mathrm{Ca}^{2+}=3.9 \mathrm{cmol}_{\mathrm{c}} \mathrm{dm}^{-3}$; $\mathrm{Mg}^{2+}=1.2 \mathrm{cmol}_{\mathrm{c}} \mathrm{dm}^{-3} ; \mathrm{Al}^{3+}=0.0 \mathrm{cmol}_{\mathrm{c}} \mathrm{dm}^{-3}$. In autumn-winter, soil characteristics were as follows: $\mathrm{pH}$ in $\mathrm{H}_{2} \mathrm{O}(1: 2.5)=6.5 ; \mathrm{OM}=12.7 \mathrm{~g} \mathrm{~kg}^{-1} ; \mathrm{P}=20.0$ $\mathrm{mg} \quad \mathrm{dm}^{-3} ; \quad \mathrm{K}^{+}=0.4 \quad \mathrm{cmol}_{\mathrm{c}} \quad \mathrm{dm}^{-3}$; $\mathrm{Ca}^{2+}=3.4 \mathrm{cmol}_{\mathrm{c}} \mathrm{dm}^{-3} ; \mathrm{Mg}^{2+}=1.1 \mathrm{cmol}_{\mathrm{c}} \mathrm{dm}^{-3}$; $\mathrm{Al}^{3+}=0.0 \mathrm{cmol}_{\mathrm{c}} \mathrm{dm}^{-3}$.

The experimental procedure used in each experiment consisted of a randomized complete block design with three replications and treatments arranged in a $4 \times 4$ factorial scheme. The first factor was composed of four amounts of roostertree biomass $\left(5.4 ; 8.8,12.2\right.$, and $15.6 \mathrm{t} \mathrm{ha}^{-1}$ on a dry basis) and the second factor of four incorporation times $(0,10,20$, and 30 days before lettuce transplanting).

Each experimental unit covered a total area of $1.44 \mathrm{~m}^{2}$, with a harvest area of $0.64 \mathrm{~m}^{2}$. Six rows or planting lines were arranged transversely in each plot, with $0.20 \mathrm{~m}$ spacing between lines and $0.20 \mathrm{~m}$ between plants. For the experiments, was chose the cultivar 'Babá de Verão', suitable for cultivation in the northeast of Brazil. Soil preparation in each experiment consisted of the lifting of beds using hoes.

Roostertree biomass was collected from locations in the vicinity of UAST and crushed using a conventional forage machine to obtain fragments between two and three centimeters. Subsequently, the fragments were dried to obtain a hay-like condition ( $10 \%$ moisture) and nutrient contents were determined, with the following results: $\mathrm{N}=17.4 \mathrm{~g} \mathrm{~kg}^{-1} ; \mathrm{P}=4.4 \mathrm{~g} \mathrm{~kg}^{-1} ; \mathrm{K}=23.5 \mathrm{~g} \mathrm{~kg}^{-1}$; $\mathrm{Ca}=14.3 \mathrm{~g} \mathrm{~kg}^{-1} ; \mathrm{Mg}=23.0 \mathrm{~g} \mathrm{~kg}^{-1} ; \mathrm{C} / \mathrm{N}=25 / 1$.

Manure was incorporated in the $0-0.20 \mathrm{~m}$ soil layer in the experimental plots, according to the treatments. The plots were irrigated daily in two shifts in order to promote soil microbial activity, stimulating organic matter mineralization. For irrigation, was used a micro-sprinkler system providing a water sheet of approximately $8 \mathrm{~mm}$ day $^{-1}$.

Seedling production was performed in expanded polystyrene trays with 128 cells in a screen nursery with $50 \%$ shading and the use of the commercial substrate Plantmax $\mathrm{HT}^{\circledR}$. This compound consists of pine bark, peat, and vermiculite expanded with $50 \%$ moisture. Water retention capacity was $100 \%, \mathrm{pH}$ in water was $5.8(+/-0.5)$; electrical conductivity in the proportion of water: substrate $2: 1$ was $1.7(+/-0.3) \mathrm{mS} \mathrm{cm}^{-1}$ and in 5:1 $1.0(+/-0.3) \mathrm{mS}$ $\mathrm{cm}^{-1}$ (DDL AGROINDÚSTRIA, 2012). In the first cropping season (spring), planting was performed on September 20, 2011, while in the second cropping season (autumn-winter), seedlings were planted on May 25, 2012. On October 16, 2011 (spring) and June 19, 2012 (autumn-winter), after the last incorporation of the green manure, seedlings were transplanted. Manual weeding was carried out whenever necessary.

In spring, the lettuce crop was harvested at 32 days after transplanting (DAT), while in autumn-winter, was harvested at 36 DAT. After harvesting, were evaluated the following characteristics: shoot plant diameter, number of leaves per plant (using a sample of 16 plants, counting the number of leaves longer than five centimeters from the basal leaves up to the last open sheet); plant height from the base to the tip of the highest leaf (cm, using a sample of 16 plants), yield of green mass $\left(\mathrm{t} \mathrm{ha} \mathrm{h}^{-1}\right.$, obtained from the shoot fresh mass of all plants in the harvest area), and shoot dry $\operatorname{mass}\left(\mathrm{t} \mathrm{ha}^{-1}\right.$, estimated from plant dry mass after drying at $65^{\circ} \mathrm{C}$ until constant weight).

Analyzes of variance were made for the characteristics through the application SISVAR 3:01 (FERREIRA, 2003). A joint analysis of these characteristics was performed. Fitting procedures of response curves were performed between evaluated traits and quantitative factors using SigmaPlot 12.0 (SYSTAT SOFTWARE, 2011). Tukey's test $(\mathrm{p}<0.05)$ was used to compare means between cropping seasons.

\section{RESULTS AND DISCUSSION}

Based on the results of the joint analysis of the variables evaluated as a function of the growing seasons, of the amounts of roostertree biomass, and of incorporation times, were observed a double interaction between planting dates and roostertree biomass as well as between cropping seasons and incorporation times for the variable plant diameter. For the variable number of leaves per plant, was observed an isolated effect of the quantities of green manure and an interaction of the cultivation seasons with incorporation times. There was also an interaction between the three factors (green manure, cultivation season and incorporation time) for plant height, green mass yield and dry mass of shoots (Table 1). 
Table 1. Summary of the analysis of variance for plant height (PH), plant diameter (PD), number of leaves per plant (NL), green mass yield (GMY) and dry shoot mass (DSM) of lettuce plants fertilized with roostertree manure in two cropping seasons.

\begin{tabular}{lcrrrrr}
\hline & & PD & NL & PH & GMY & DSM \\
\cline { 3 - 7 } \multicolumn{1}{c}{ Sources of Variation } & d.f. & & & \multicolumn{1}{c}{$\mathrm{F}_{\text {calculated }}$} & & \\
\hline Cropping Seasons (S) & 1 & $622.61^{* *}$ & $311.55^{* *}$ & $309.53^{* *}$ & $1,609.98^{* *}$ & $288.94^{* *}$ \\
Roostertree amounts (A) & 3 & $50.09^{* *}$ & $26.47^{* *}$ & $22.06^{* *}$ & $320.78^{* *}$ & $92.20^{* *}$ \\
Incorporation times (T) & 3 & $34.12^{* *}$ & $43.72^{* *}$ & $43.59^{* *}$ & $380.71^{* *}$ & $87.56^{* *}$ \\
S x A & 3 & $22.35^{* *}$ & $1.50^{\text {ns }}$ & $2.66^{\text {ns }}$ & $5.31^{* *}$ & $7.13^{* *}$ \\
S x T & 3 & $7.35^{* *}$ & $11.16^{* *}$ & $23.47^{* *}$ & $87.94^{* *}$ & $24.25^{* *}$ \\
A x T & 9 & $0.41^{\text {ns }}$ & $1.91^{\text {ns }}$ & $3.37^{* *}$ & $18.72^{* *}$ & $3.13^{* *}$ \\
S x A x T & 9 & $0.44^{\text {ns }}$ & $0.81^{\text {ns }}$ & $4.61^{* *}$ & $5.88^{* *}$ & $2.48^{*}$ \\
\hline CV (\%) & 9.91 & 8.24 & 7.86 & 5.74 & 8.10 \\
\hline
\end{tabular}

ns; $* *$ and $*$ : not significant, significant at $1 \%$ and $5 \%$ probability in the $\mathrm{F}$ test, respectively.

Plant diameter in both cropping seasons increased linearly with increasing amounts of green manure (Figure 2A). For each ton added to the soil,



were registered increases of $0.56 \mathrm{t} \mathrm{ha}^{-1}$ (spring) and $0.11 \mathrm{t} \mathrm{ha}^{-1}$ (autumn-winter). Plant diameter was higher in cultures planted in spring (Table 2).
○一 Autumn-winter: $\mathrm{y}=18.2894 * *+0.0056 * * \mathrm{x}^{2}-7.332 \mathrm{E}^{-06 * *} \mathrm{x}^{4}\left(\mathrm{R}^{2}=0.99 * *\right)$



Times of roostertree incorporation (days)

Figure 2. Diameter of lettuce plants impacted by roostertree biomass amounts (A) and of incorporation times (B) in each cropping season.

Table 2. Mean values of diameter of lettuce plants in the interaction of the cropping seasons with the roostertree biomass.

\begin{tabular}{lcccc}
\hline Cropping seasons & \multicolumn{4}{c}{ Roostertree amounts $\left(\mathrm{t} \mathrm{ha}^{-1}\right)$} \\
\cline { 2 - 5 } & 5.4 & \multicolumn{4}{c}{ Plant diameter $(\mathrm{cm})$} & 15.6 \\
\hline & \multicolumn{4}{c}{2.2} \\
Spring & $20.55 \mathrm{a}^{1}$ & $23.01 \mathrm{a}$ & $25.15 \mathrm{a}$ & $26.18 \mathrm{a}$ \\
Autumn-winter & $17.79 \mathrm{~b}$ & $18.38 \mathrm{~b}$ & $18.67 \mathrm{~b}$ & $18.97 \mathrm{~b}$ \\
\hline
\end{tabular}

${ }^{1}$ Means followed by different lowercase letters in each column differ statistically by Tukey's test at $5 \%$ probability.

Were observed crescent values of plant diameter until 25.35 (spring) and $19.35 \mathrm{~cm}$ (autumn-winter) at day 12 and 20, respectively, after roostertree incorporation, followed by reduced diameter (Figure 2B). Plant diameter was higher in the first than in the second cultivation season, regardless of the permanency of the green manure (Table 3).

Table 3. Mean values of plant diameter and number of leaves per plant for L. sativa in the interaction cropping seasons and times of incorporation of roostertree manure into the soil.

\begin{tabular}{lcccc}
\hline Cropping seasons & \multicolumn{4}{c}{ Times of roostertree incorporation (days) } \\
\cline { 2 - 5 } & 0 & 10 & 20 & 30 \\
\hline & \multicolumn{4}{c}{ Plant diameter $(\mathrm{cm})$} \\
Spring & $23.65 \mathrm{a}$ & $25.56 \mathrm{a}$ & $24.27 \mathrm{a}$ & $21.41 \mathrm{a}$ \\
Autumn-winter & $18.28 \mathrm{~b}$ & $18.79 \mathrm{~b}$ & $19.35 \mathrm{~b}$ & $17.39 \mathrm{~b}$ \\
\hline
\end{tabular}

${ }^{1}$ Means followed by different lowercase letters in each column differ statistically by Tukey's test at $5 \%$ probability. 
E. G. F. SOUZA et al.

Table 3. Continuation.

\begin{tabular}{lcccc}
\hline Cropping seasons & \multicolumn{4}{c}{ Times of roostertree incorporation (days) } \\
\cline { 2 - 5 } & 0 & 10 & 20 & 30 \\
\hline & \multicolumn{4}{c}{ Number of leaves per plant } \\
Spring & $31.00 \mathrm{a}$ & $35.25 \mathrm{a}$ & $32.76 \mathrm{a}$ & $26.20 \mathrm{a}$ \\
Autumn-winter & $21.64 \mathrm{~b}$ & $23.42 \mathrm{~b}$ & $27.20 \mathrm{~b}$ & $20.58 \mathrm{~b}$ \\
\hline
\end{tabular}

${ }^{1}$ Means followed by different lowercase letters in each column differ statistically by Tukey's test at $5 \%$ probability.

The number of leaves per plant increased with increasing doses of roostertree manure, reaching a maximum of 29.32 leaves with the amount of $15.6 \mathrm{t} \mathrm{ha}^{-1}$ of manure (Figure 3A). Maximum values of leaves per plant was 34.94 in spring and 27.11 in autumn-winter, when green manure was incorporated

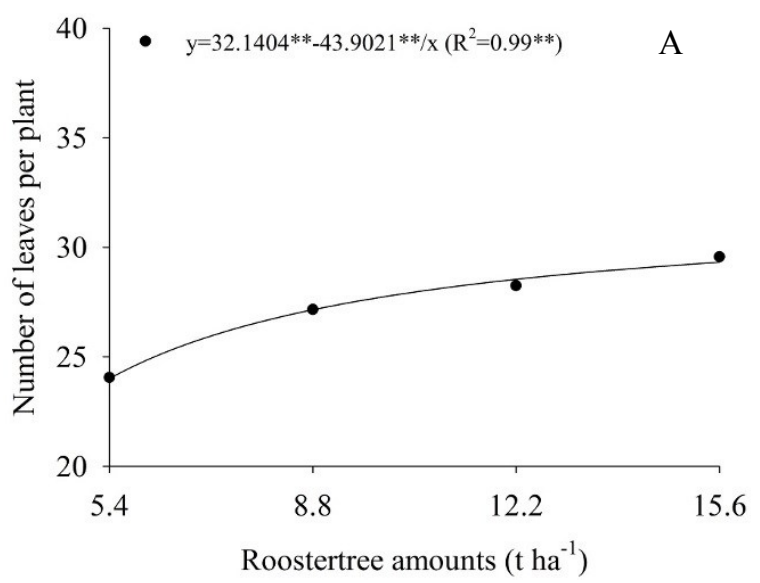

into the soil 12 and 21 days before seedling transplanting, respectively, decreasing then until the last time of incorporation (Figure 3B). Cultivation in spring resulted in higher leaf numbers than cultivation in autumn-winter (Table 3).



Figure 3. Number of leaves per lettuce plant as a function of the amount of roostertree biomass (A) and incorporation times of biomass within each cropping season (B).

In general, increased amounts of roostertree biomass resulted in increased plant height (Figures $4 \mathrm{~A}, \mathrm{~B})$. In the spring cropping, fertilization with $15.6 \mathrm{t} \mathrm{ha}^{-1}$, associated with 10-day incorporation time before lettuce transplanting, promoted greater plant height values $(22.04 \mathrm{~cm})$ (Figure 4A). In the second cropping season (autumn-winter), was observed a mean plant height of $15 \mathrm{~cm}$ when fertilized with $15.6 \mathrm{t} \mathrm{ha}^{-1}$ at 20 days before transplanting (Figure 4B).

In spring, peaks of plant height were obtained close to 12 days after transplanting for all the combinations of the factorial scheme, except for the amount of $15.6 \mathrm{t} \mathrm{ha}^{-1}$ (Figure 4C), in which no regression was adjusted (mean of $17.9 \mathrm{~cm}$ ). The incorporation time of 12.7 days together with the amount of $12.2 \mathrm{t} \mathrm{ha}^{-1}$ gave the highest value of plant height $(19.9 \mathrm{~cm})$ (Figure 4C). In the autumn-winter planting, higher plant height $(14.98 \mathrm{~cm})$ was measured for the optimized incorporation time of 20.9 days associated with the amount of $15.6 \mathrm{tha}^{-1}$ of green manure (Figure 4D).

In the first cropping season (spring), there was a growing response in the green mass yield as a function of green manure dose, in which higher productivity $\left(38.57 \mathrm{t} \mathrm{ha}^{-1}\right)$ was obtained with an amount of $15.6 \mathrm{t} \mathrm{ha}^{-1}$ roostertree manure, incorporated 10 days before lettuce transplanting (Figure 5A). This increase between the lowest and highest amount of fertilizer was approximately $68 \%$. In the second cropping season (Figure 5B), maximum yields were achieved with an amount of $15.6 \mathrm{t} \mathrm{ha}^{-1}$ of roostertree manure, incorporated into the soil at $10\left(23.85 \mathrm{t} \mathrm{ha}^{-1}\right)$ and 20 days $\left(24.05 \mathrm{t} \mathrm{ha}^{-1}\right)$ after transplanting.

Incorporation time at 10.89 days, together with a dose of $15.6 \mathrm{t} \mathrm{ha}^{-1}$ roostertree, provided the highest value of green mass yield in spring cultivation (39.61 $\mathrm{t} \mathrm{ha} \mathrm{ha}^{-1}$ ) (Figure 5C). In the autumn-winter cultivation, association of the optimized time of 15 days with the highest biomass of green manure was highlighted (Figure 5D), but with lower results than in spring $\left(25.94 \mathrm{t} \mathrm{ha}^{-1}\right)$. There was no adjustment of regression curves for the treatments with respect to amounts of 5.4, 8.8, and $12.2 \mathrm{tha}^{-1}$. 
A. Spring

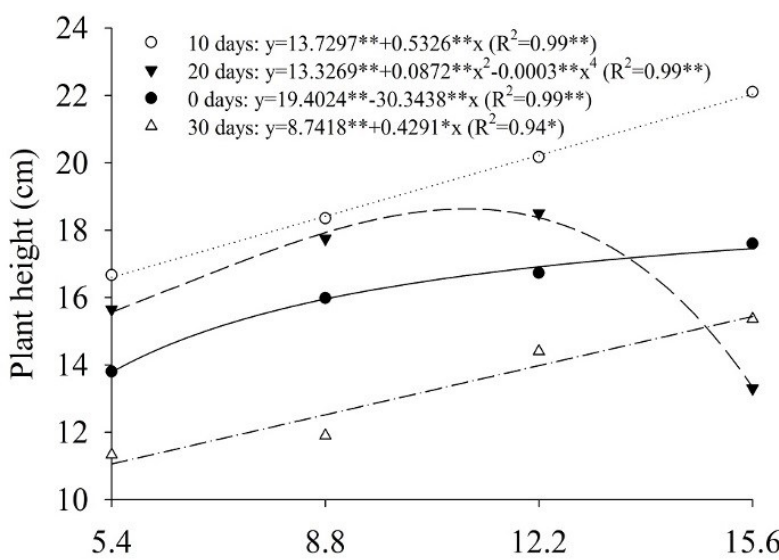

Roostertree amounts $\left(\mathrm{tha}^{-1}\right)$



Times of roostertree incorporation (days)
B.

Autumn-winter


Times of roostertree incorporation (days)

Figure 4. Lettuce plant height as a function of roostertree biomass and manure incorporation time (A. spring; B. autumn-winter) and manure incorporation time and roostertree biomass (C. spring; D. autumn-winter) within each cropping season.

Dry mass of the shoot lettuce reached a maximum value of $2.34 \mathrm{tha}^{-1}$ in the spring season, associated with a green manure amount of $15.6 \mathrm{tha}^{-1}$ and incorporation time of 10 days before lettuce transplanting (Figure 6A), which was an increase of $66 \%$ compared to lower manure doses. The combination of the amount of $15.6 \mathrm{t} \mathrm{ha}^{-1}$ of roostertree manure with the time of 20 days resulted in $1.73 \mathrm{t} \mathrm{ha}^{-1}$ of dry mass yield in autumn-winter (Figure 6B), which was higher than in the other treatments and statistically lower than in the first cropping season.

In the spring cultivation, the dry mass yield of lettuce increased quadratically with the incorporation times and the amount of $15.6 \mathrm{t} \mathrm{ha}^{-1}$ of roostertree manure, reaching a maximum value of $2.33 \mathrm{t} \mathrm{ha}^{-1}$ at 12.81 days and subsequently decreasing until the last incorporation time (Figure 6C). In the second growing season (autumn-winter), were estimated higher yields of dry mass $\left(1.73 \mathrm{t} \mathrm{ha}^{-1}\right)$ using $15.6 \mathrm{t} \mathrm{ha}^{-1}$ of green manure and an incorporation time of 20.6 days (Figure 6D).

In both growing seasons, plant diameter and height, number of leaves per plant and green and dry mass yields increased with increased amounts of roostertree manure. These positive results are due probably to the greater availability of macro and micronutrients, which were released to the soil via roostertree manure, promoting soil fertility (BATISTA et al., 2013; GÓES et al., 2011). Fertilization with plant species that occur spontaneously in the region also favors microbiological soil aspects, with an increase in the number of fungi, actinomycetes, and other bacteria beneficial for plant growth (BATISTA et al., 2013). 

A.
Spring
B.
Autumn-winter
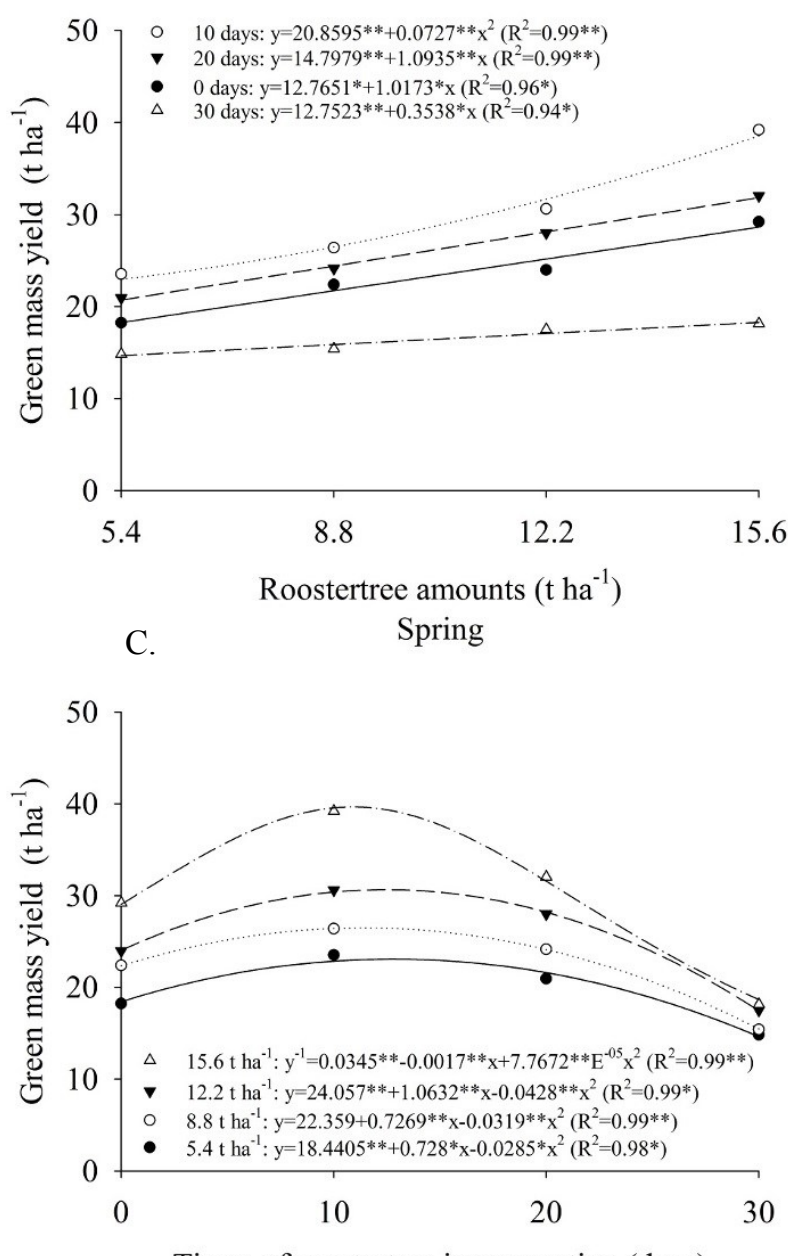

Times of roostertree incorporation (days)
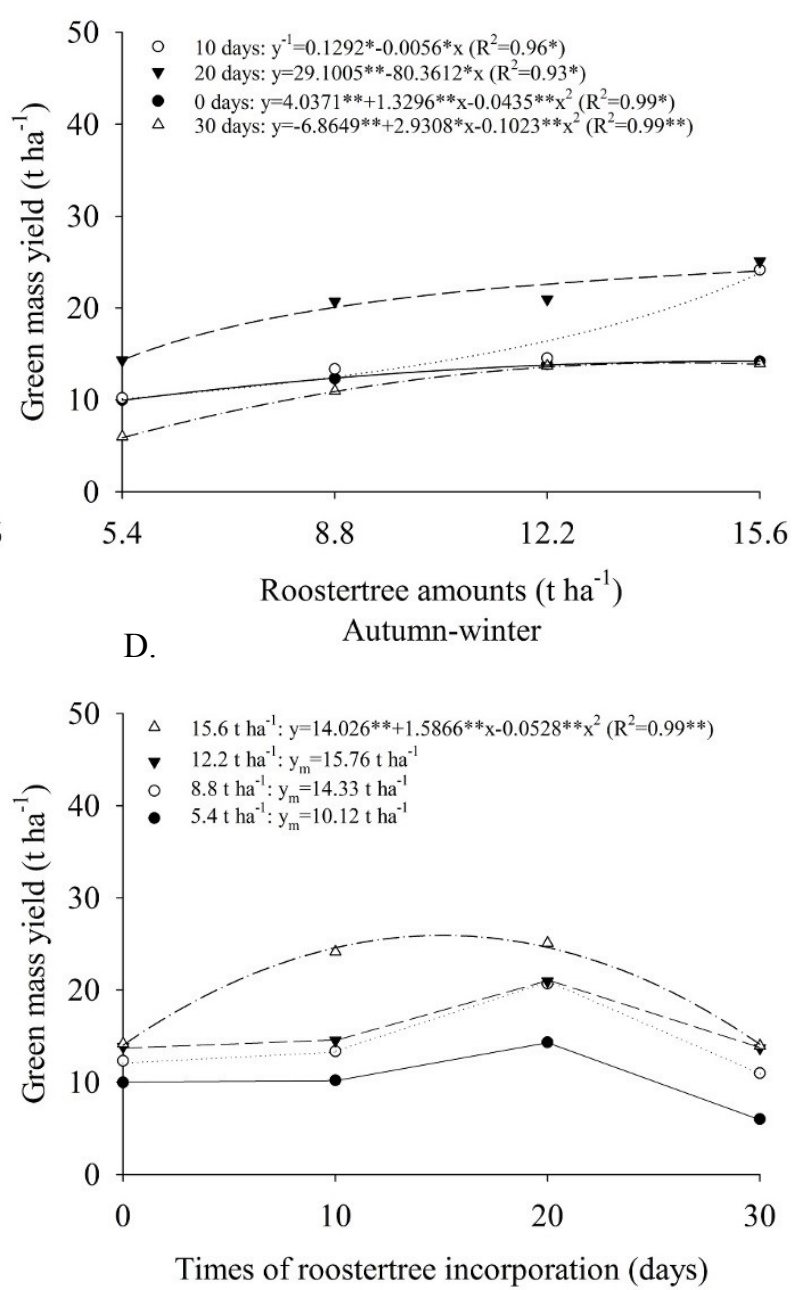

Figure 5. Green mass yield of lettuce as a function of the interaction between roostertree biomass and incorporation times (A. spring; B. autumn-winter) and manure incorporation time and roostertree biomass (C. spring; D. autumn-winter) within each cropping season.

In a similar study, Linhares (2009), cultivating the lettuce cultivar 'Babá de Verão' between winter and spring in Mossoró, achieved a plant height of $16.13 \mathrm{~cm}$, plant diameter of $22.90 \mathrm{~cm}$, leaf number of 31.28 , fresh yield of $14.54 \mathrm{t} \mathrm{ha}^{-1}$, and dry mass accumulation of $1.57 \mathrm{tha}^{-1}$, fertilizing with $15.6 \mathrm{t} \mathrm{ha}^{-1}$ of roostertree manure incorporated into the soil 15 days before transplanting. The author found that using roostertree manure resulted in better plant development than using oneleaf senna ( $S$. uniflora) as manure. Using the same location and growing seasons, Góes et al. (2011) obtained a maximum value of green mass yield of the lettuce cultivar 'Babá de Verão'. (15.33 t ha ${ }^{-1}$ ) with incorporation of $6.68 \mathrm{t} \mathrm{ha}^{-1}$ of hairy woodrose 30 days before lettuce transplanting. These values were much lower than those found in our study, probably due to the high average air temperature (above $28^{\circ} \mathrm{C}$ ) in both cultivation periods.

In the literature, recommendations for fertilizer amounts in lettuce cultivation are often similar to those for other leafy vegetable crops and are derived from researches under different conditions than those prevailing in the Brazilian semiarid region. For example, for the states Rio Grande do Sul and Santa Catarina, recommended fertilizer amounts for the cultivation of lettuce, chicory, endive, and arugula are $80-200 \mathrm{~kg} \mathrm{ha}^{-1} \mathrm{~N}$, 17-87 $\mathrm{kg} \mathrm{ha}^{-1} \mathrm{P}$, and 75-200 $\mathrm{kg} \mathrm{ha}^{-1} \mathrm{~K}$ (SBCS, 2004). Sousa et al. (2008) proposed the application of $30 \mathrm{~kg} \mathrm{ha}^{-1}$ of $\mathrm{N}$ at planting and $40 \mathrm{~kg} \mathrm{ha}^{-1}$ in coverage to 15 days after sowing, $26-52 \mathrm{~kg} \mathrm{ha}^{-1}$ of $\mathrm{P}_{2} \mathrm{O}_{5}$, and 62-166 $\mathrm{kg} \mathrm{ha}^{-1} \mathrm{~K}$ for the state of Pernambuco. Trani et al. (2014) recommend the use of $30-50 \mathrm{~kg} \mathrm{ha}^{-1}$ of $\mathrm{N}$ at planting and $60-100 \mathrm{~kg} \mathrm{ha}^{-1} \mathrm{~N}$ in coverage (two to four applications), 26-139 $\mathrm{kg} \mathrm{ha}^{-1}$ $\mathrm{P}$, and $25-100 \mathrm{~kg} \mathrm{ha}^{-1} \mathrm{~K}$. Grangeiro et al. (2006) evaluated nutrient accumulation in three lettuce cultivars under the conditions of Mossoró-RN and found that the cultivar 'Babá de Verão' demanded the following amounts of fertilizer 27 days after transplanting: $75 \mathrm{~kg} \mathrm{ha}^{-1} \mathrm{~N}, 42.5 \mathrm{~kg} \mathrm{ha}^{-1} \mathrm{P}$, $112.5 \mathrm{~kg} \mathrm{ha}^{-1} \mathrm{~K}, 13.5 \mathrm{~kg} \mathrm{ha}^{-1}$ of $\mathrm{Ca}$, and $35 \mathrm{~kg} \mathrm{ha}^{-1}$ $\mathrm{Mg}$. 
A Spring B Autumn-winter
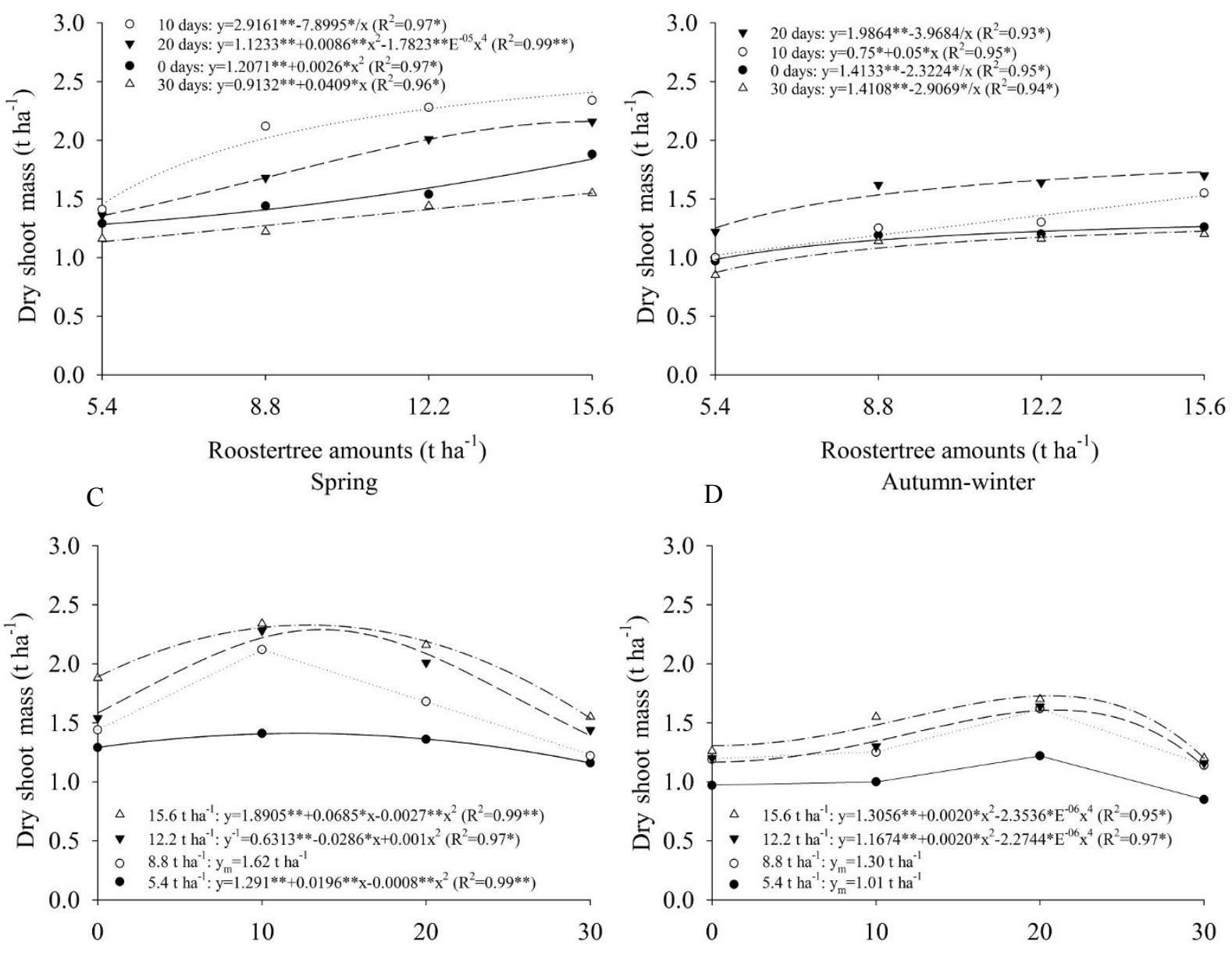

Times of roostertree incorporation (days)

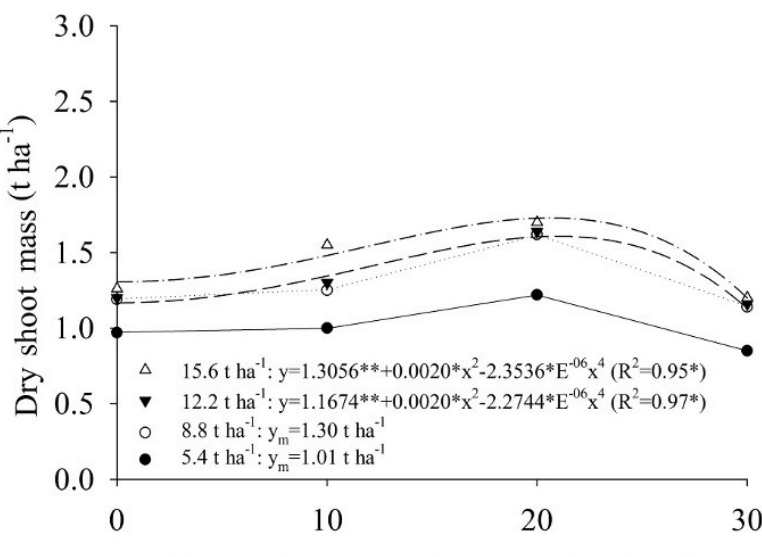

Times of roostertree incorporation (days)

Figure 6. Dry shoot mass of lettuce as a function of the interaction between roostertree biomass and incorporation times of green manure (A. spring; B. autumn-winter) and manure incorporation time and roostertree biomass (C. spring; D. autumn-winter) within each cropping season.

From nutrient analysis of the roostertree, it appears that the quantities used in the different treatments in our study $\left(5.4,8.8,12.2\right.$, and $15.6 \mathrm{t} \mathrm{ha}^{-1}$ on a dry basis) correspond to a fertilization with 93.9 to $271.4 \mathrm{~kg} \mathrm{ha}^{-1} \mathrm{~N}, 23.7$ to $68.6 \mathrm{~kg} \mathrm{ha}^{-1} \mathrm{P}, 126.9$ to $366.6 \mathrm{~kg} \mathrm{ha}^{-1} \mathrm{~K}, 77.2$ to $223.1 \mathrm{~kg} \mathrm{ha}^{-1}$ of $\mathrm{Ca}$, and 124.2 to $358.80 \mathrm{~kg} \mathrm{ha}^{-1} \mathrm{Mg}$; therefore, were applied higher doses than those required by this cultivar. It should be noted that organic fertilizers, unlike chemical fertilizers, do not readily supply plant-available nutrients, as mineralization processed depend on factors such as current and physical, chemical, and biological soil conditions, $\mathrm{C} / \mathrm{N}$ ratio of the material and of the meteorological impacts (XU; HIRATA, 2005).

In this sense, studying incorporation time of roostertree manure into the soil allowed to identify the moment of synchrony between mineralization of the vegetable residue and the period of maximum nutritional requirement of arugula (MYERS et al., 1994), i.e., when green manure was incorporated into the soil at 10 (spring) and 20 (autumn-winter) days before seedling transplantation, optimal results were obtained. Lettuce plants have higher nutrient demands from 22 to 27 days after transplanting (GRANGEIRO et al., 2006), therefore requiring 32-37 (spring) and 42-47 (autumn-winter) days of incubation of green manure for high productivity. Torres et al. (2005) found that higher N mineralization rates in crops used as green manures occurred in the first 42 days after being desiccated, which was related to low $\mathrm{C} / \mathrm{N}$ ratios of the plant material (20-25/1). A similar $\mathrm{C} / \mathrm{N}$ ratio was observed in the chemical composition of the roostertree.

An influence of weather conditions was observed in the different cultural cycles of lettuce in spring (32 DAT) and autumn-winter (36 DAT), resulting in higher yields in the first growing season. In the spring, were observed average temperatures above $25.7^{\circ} \mathrm{C}$, solar radiation exceeding 21.3 $\mathrm{MJ} \mathrm{m}^{-2}$ day $^{-1}$ and days with more than 12 hours of light (Figure 1), which possibly had a positive effect on lettuce development. On the other hand, average temperatures close to $25^{\circ} \mathrm{C}$ and a reduced photoperiod (below 12 hours) in the autumn-winter cultivation only slightly stimulated lettuce growth. 
These results demonstrate the adaptation of the cultivar 'Babá de Verão' to warmer weather conditions and contrast with the findings obtained by Souza et al. (2008), which reported effects of medium-high temperatures (above $25^{\circ} \mathrm{C}$ ), stimulating higher stem length and bolting and reducing leaf numbers.

Queiroga et al. (2001) evaluated spring production of the smooth lettuce cv. 'Regina' under shade cloth in Mossoró-RN, measuring average height, plant diameter, number of leaves per plant, dry mass, and productivity values of $25 \mathrm{~cm}, 30 \mathrm{~cm}$, 30 leaves, $1.97 \mathrm{t} \mathrm{ha}^{-1}$, and $46.97 \mathrm{t} \mathrm{ha}^{-1}$, respectively, which were similar to those obtain in this study. In the same planting season and municipality, Grangeiro et al. (2006) conducted experiments with cv. 'Babá de Verão', reaching a green mass yield of $24.6 \mathrm{t} \mathrm{ha}^{-1}$, which is lower than that obtained in the present work, probably due to the high daytime temperatures during the growing season $\left(28.6^{\circ} \mathrm{C}\right)$. Studying the productive behavior of lettuce cultivars in different seasons in Mossoró, Silva (2014) found that cropping seasons influenced all evaluated traits, with winter being the most suitable season, showing average temperatures of $27^{\circ} \mathrm{C}$.

Based on the results from our study, fertilization of the lettuce cultivar 'Babá de Verão' with roostertree manure in recommended in both cropping seasons, but planting in the spring with addition of $15.6 \mathrm{t} \mathrm{ha}^{-1}$ of green manure 10 days before seedling transplanting results in $60 \%$ increase in green mass yield in relation to cultivation in autumn-winter.

\section{CONCLUSIONS}

The best agronomic performance of the lettuce cv. 'Babá de Verão' was obtained via manuring with $15.6 \mathrm{t} \mathrm{ha}^{-1}$ of roostertree.

The ideal time of incorporation of the green manure was 10 days (spring) and 20 days (autumn-winter) before seedling transplanting.

Spring cultivation and fertilization with roostertree manure provided higher accumulation of fresh and dry shoot mass.

\section{ACKNOWLEDGEMENTS}

We thank the Programa de Pós-Graduação em Produção Vegetal da UFRPE-UAST for the opportunity to carry out this work. Also, we wish to thank the Fundação de Amparo à Ciência e Tecnologia do Estado de Pernambuco (FACEPE) for financial support and the Coordenação de Aperfeiçoamento de Pessoal de Nível Superior (CAPES) for providing a Masters scholarship.

\section{REFERENCES}

ALMEIDA, A. E. S. et al. Eficiência agronômica do consórcio alface-rúcula fertilizado com flor-de-seda. Revista Caatinga, Mossoró, v. 28, n. 3, p. 79-85, 2015.

ANDRADE, M. V. M. et al. Produtividade e qualidade da flor-de-seda em diferentes densidades e sistemas de plantio. Revista Brasileira de Zootecnia, Viçosa, v. 37, n. 1, p. 1-8, 2008.

BATISTA, M. A. V. et al. Atributos microbiológicos do solo e produtividade de rabanete influenciados pelo uso de espécies espontâneas. Horticultura Brasileira, Brasília, v. 31, n. 4, p. 587-594, 2013.

BEZERRA NETO, F. et al. Desempenho agronômico da alface em diferentes quantidades e tempos de decomposição de jitirana verde. Revista Brasileira de Ciências Agrárias, Recife, v. 6, n. 2 , p. 236-242, 2011.

BEZERRA NETO, F. et al. Otimização agroeconômica da cenoura fertilizada com diferentes doses de jitirana. Revista Ciência Agronômica, Fortaleza, v. 45, n. 2, p. 305-311, 2014.

CARVALHO JÚNIOR, S. B. et al. Produção e avaliação bromatológica de espécies forrageiras irrigadas com água salina. Revista Brasileira de Engenharia Agrícola e Ambiental, Campina Grande, v. 14, n. 10, p. 1045-1051, 2010.

DDL AGROINDÚSTRIA. Substrato Plantmax HT

Hortaliças. 2012. Disponível em: <http:// www.ddlagro.com.br/plantmax.html $>$. Acesso em: 12 jan. 2013.

FERREIRA, D. F. Programa SISVAR: sistema de análise de variância. Versão 4.6 (Build 6.0). Lavras: DEX/UFLA, 2003.

GÓES, S. B. et al. Productive performance of lettuce at different amounts and times of decomposition of dry scarlet starglory. Revista Ciência Agronômica, Fortaleza, v. 42, n. 4, p. 1036-1042, 2011.

GRANGEIRO, L. C. et al. Acúmulo de nutrientes por três cultivares de alface cultivadas em condições do Semi-Árido. Horticultura Brasileira, Brasília, v. 24, n. 2, p. 190-194, 2006.

KENTER, C.; HOFFMANN, C. M.; MARLANDER, B. Effects of weather variables on sugar beet yeld development (Beta vulgaris L.). European Journal of Agronomy, Copenhagen, v. 24, n. 1, p. 62-69, 2006.

LINHARES, P. C. F. Vegetação espontânea como 
adubo verde no desempenho agroeconômico de hortaliças folhosas. 2009. $109 \mathrm{f}$. Tese (Doutorado em Fitotecnia: Área de Concentração em Agricultura Tropical) - Universidade Federal Rural do Semi-Árido, Mossoró, 2009.

MEDEIROS, S. S. et al. Estimativa e espacialização das temperaturas do ar mínimas, médias e máximas na Região Nordeste do Brasil. Revista Brasileira de Engenharia Agrícola e Ambiental, Campina Grande, v. 9, n. 2, p. 247-255, 2005.

MYERS, R. J. K. et al. The synchronization of nutrient mineralization and plant nutrient demand. In: WOOMER, P. L.; SWIFT, M. J. (Eds.). The biological management of tropical soil fertility. New York: John Wiley and Sons, 1994. p. 81-116.

OLIVEIRA, M. K. T. et al. Desempenho agronômico da cenoura adubada com jitirana antes de sua semeadura. Revista Ciência Agronômica, Fortaleza, v. 42, n. 2, p. 364-372, 2011.

QUEIROGA, R. C. F. et al. Produção de alface em função de cultivares e tipos de tela de sombreamento nas condições de Mossoró. Horticultura Brasileira, Brasília, v. 19, n. 3, p. 192-196, 2001.

SILVA, M. L. et al. Produção de beterraba fertilizada com jitirana em diferentes doses e tempos de incorporação ao solo. Revista Brasileira de Engenharia Agrícola e Ambiental, Campina Grande, v. 15, n. 8, p. 801-809, 2011.

SILVA, O. M. P. Desempenho produtivo e qualitativo de cultivares de alface em diferentes épocas de plantio em Mossoró-RN. 2014. $102 \mathrm{f}$. Dissertação (Mestrado em Fitotecnia: Área de Concentração em Agricultura Tropical) Universidade Federal Rural do Semi-Árido, Mossoró, 2014.

SOCIEDADE BRASILEIRA DE CIÊNCIA DO SOLO - SBCS. Manual de adubação e de calagem para os Estados do Rio Grande do Sul e de Santa Catarina. 10. ed. Porto Alegre, RS: Comissão de Química e Fertilidade do Solo, 2004. 400 p.

SOUSA, A. R. et al. Alface: Lactuca sativa L.. In.: CAVALCANTI, F. J. A. (Ed.). Recomendações de adubação para o estado de Pernambuco: $2^{\mathrm{a}}$ aproximação. 3. ed. rev. Recife: IPA, 2008. cap. 9, p. 112 .

SOUZA, M. C. M. et al. Variabilidade genética para características agronômicas em progênies de alface tolerantes ao calor. Horticultura Brasileira, Brasília, v. 26, n. 3, p. 354-358, 2008.
DESENVOLVIMENTO DO NORDESTE SUDENE. Dados pluviométricos mensais do Nordeste: Estado de Pernambuco. Recife, PE: Grafset, 1990. 363 p. (Séries Pluviométricas, 6).

SYSTAT SOFTWARE. SigmaPlot for Windows. Version 12.0. San Jose: Systat Software Inc., 2011.

TORRES, J. L. R. et al. Decomposição e liberação de nitrogênio de resíduos culturais de plantas de cobertura em um solo de cerrado. Revista Brasileira de Ciência do Solo, Viçosa, v. 29, n. 4, p. 609-618, 2005.

TRANI, P. E. et al. Calagem e adubação da alface, almeirão, agrião d'água, chicória, coentro, espinafre e rúcula. Campinas: IAC, 2014. 16 p. (IAC. Informações Tecnológicas, 97).

XU, X.; HIRATA, E. Decomposition patterns of leaf litter of seven common canopy species in a subtropical Forest: $\mathrm{N}$ and $\mathrm{P}$ dynamics. Plant and Soil, Netherlands, v. 273, n. 1-2, p. 279-289, 2005. 